\title{
Rola prípadového manažéra v oblasti starostlivosti o l'udí so zdravotným postihnutím
}

\section{The Role of Case Manager in the Field of Care for People with Disabilities}

Jana Levická1, Fakulta sociálnych vied UCM, Trnava

Michaela Vaceková ${ }^{2}$ Fakulta sociálnych vied UCM, Trnava

Emma Valigurskáa ${ }^{3}$, Fakulta sociálnych vied UCM, Trnava

\section{Abstrakt}

Teoretickým východiskom príspevku je Senov koncept sociálnej spravodlivosti fokusovaný na l'udí so zdravotným postihnutím. Inklúzia l'udí so špecifickými potrebami predpokladá, že jednotlivé subsystémy zabezpečujúce podporu a starostlivost’ o týchto klientov sú funkčne prepojené. V SR napriek dlhoročnej snahe o zavedenie komplexnej koordinovanej starostlivosti nie sú vytvorené legislatívne a štrukturálne podmienky, ktoré by podporovali vznik takéhoto typu starostlivosti. Príspevok je spracovaný v dizajne teoretickej štúdie. Cielom príspevku je poukázat' na možné prínosy sociálnej práce, ktorá by prostredníctvom role prípadového manažéra mohla prispiet’ k preklenutiu rezortnej izolácie a k vytvoreniu funkčného systému fokusovaného na ludí so zdravotným postihnutím.

\section{Klúčové slová}

ludia so zdravotným postihnutím, inkluzívna spoločnost', komplexná koordinovaná starostlivost', prípadový manažér, sociálna spravodlivost', sociálna práca

\section{Abstract}

The theoretical basis of the paper is Sen's concept of social justice focused on people with disabilities. The inclusion of people with specific needs presupposes that the individual subsystems providing support and care for these clients are functionally interconnected. In the Slovak Republic, despite many years of efforts to introduce comprehensive coordinated care, no legislative and structural conditions have been created that would support the emergence of this type of care. The paper is processed in the design of a theoretical study. The aim of the paper is to point out the possible benefits of social work, which could, through the role of case manager contribute to the connection of departmental isolation and the creation of a functional system aimed at people with disabilities.

\section{Keywords}

people with disabilities, inclusive society, comprehensive coordinated care, case manager, social justice, social work

\section{Úvod}

L'udia so špecifickými potrebami sú subjektmi starostlivosti rôznorodých systémov. Starostlivost' v jednotlivých subsystémoch prirodzene smeruje k zvyšovaniu kvality, ktorej nárast je možné v kontexte týchto systémov aj trvalo zaznamenávat'. Otázkou je, či segregovaný spôsob starostlivosti dostatočne prispieva

1 prof. PhDr. Mgr. Jana Levická, PhD., e-mail: jana.levicka@ucm.sk

2 Mgr. Michaela Vaceková, e-mail: vacekova1@ucm.sk

3 Mgr. Emma Valigurská, e-mail: valigurska1@ucm.sk 
ku kvalite života l'udí so špecifickými potrebami. Ďalším problémom je skrytá prepojenost' starostlivosti s politicko-ekonomickou situáciou v krajine.

Autorky príspevku ponúkajú pohl'ad na možný prínos sociálnej práce do komplexného, systémovo orientovaného prístupu starostlivosti o l’udí so špecifickými potrebami. V súlade s misiou profesie sociálna práca (Levická a kol., 2015) vystavali svoj príspevok na báze sociálnej spravodlivosti a solidarity.

\section{Senov koncept sociálnej spravodlivosti fokusovaný na l'udí so zdravotným postihnutím}

Jednou z úloh sociálnych pracovníkov je participácia na presadzovaní sociálnej spravodlivosti a solidarity v spoločnosti. Vzhl'adom k skutočnosti, že pojem sociálna spravodlivost' je jednotlivými autori objasňovaný rozlične, zvolili sme si pre náš príspevok konkrétny teoretický rámec, ktorým je Senova teória sociálnej spravodlivosti. Bazálnym dôvodom tejto vol'by je fakt, že Sen diskutuje otázky sociálnej spravodlivosti práve so zameraním na možnosti napĺňania potrieb lúuí so zdravotným postihnutím. Sen reaguje na otázky sociálneho fungovania v zmysle Bartlettovej konceptu (1970) a Rawlsovej teórie sociálnej spravodlivosti (Rawls, 1971, 2007) publikovanej začiatkom 70. rokov minulého storočia. Bartlettová predkladá sociálne fungovanie ako spoločný ciel' sociálneho pracovníka a klienta, ktorý klientovi umožňuje, aby bol plne integrovaný do spoločnosti. Autorka neskúma sociálno-politické súvislosti sociálnych problémov, ale zameriava sa prioritne na vytvorenie rámcu pre spoluprácu a následne na rozvoj klientovho potenciálu. Bartlettová považuje sociálne fungovanie za teoreticko-metodologické východisko sociálnej práce: „sociálna práca je pomáhajúca profesia, ktorej ciel'om je zabezpečit' sociálne fungovanie ludí“. Podl'a nej je ciel'om pomoci „ponúknut'lud’om také služby, ktoré im pomôžu riešit' sociálny problém“(In: Palovičová, 2011, s. 834).

Rawls v práci A Theory of Social Justice publikovanej v roku 1971 síce vymedzuje základné princípy spravodlivosti, ktorých inštitucionálne uplatňovanie v základnej spoločenskej štruktúre by malo zabezpečit' spravodlivost'v sociálnych vzt́ahoch, ale neponúka konkrétne spôsoby eliminácie špecifických nerovností, ktoré so sebou prináša l’udská diverzita (Sen, 2010). Základom Rawlsovej teórie je východisko, že všetci ludia sa rodia rovní v zmysle rovnakých príležitostí a šancí na osobný rozvoj a dosahovanie osobného blaha.

Amartya Sen od 80. rokov minulého storočia postupne publikuje svoje práce a buduje tak ucelenú teóriu, v ktorej poukazuje na politicko-ekonomické konsekvencie sociálneho fungovania so špecifickým zameraním na osoby so zdravotným postihnutím. Zo širokých možností aplikácie Senovej teórie v sociálnej práci, upriamujeme v našom príspevku pozornost' len na niekol'ko nasledovných východísk.

Sen vo svojom koncepte zavádza pojem rovnosti v základných spôsobilostiach „slobody vybrat'si život, ktorý l'udia majú dôvod si cenit" (Sen, 2010, s. 231). Spôsobilost' či schopnost' predstavujú reálnu možnost' dosiahnut v rôznych oblastiach sociálne fungovanie. Sen sa v súvislosti s problematikou sociálneho fungovania zameriava na riešenie sociálnych a globálnych nerovností, určenie kritérií kvality života a l’udského rozvoja. Vel'ký dôraz upriamuje práve na odlišné aspekty sociálneho fungovania. Senov pohl'ad na sociálne fungovanie vychádza predovšetkým z pojmu spôsobilostí v zmysle slobody či možnosti dosiahnut to, čo si človek osobne cení (Palovičová, 2011). Sen presadzuje myšlienku, že pre dosiahnutie sociálnej spravodlivosti pri jedincoch so špecifickými potrebami je nevyhnutné, aby spoločnost' vytvárala podmienky a pravidlá, ktoré umožnia dosiahnutie rovnakých šancí, akými disponujú intaktní jedinci v spoločnosti.

\section{Súčasný stav poznania}

Aplikácia Senovej teórie do praxe v oblasti starostlivosti o ludí so špecifickými potrebami je z globálneho pohl'adu rôznorodá a to aj napriek tomu, že jednotiacim prvkom by mohol byt' Dohovor OSN o právach osôb so zdravotným postihnutím (CRPD, 2006), ktorý ratifikovali vyspelé štáty. Slovenská republika k jeho ratifikácii pristúpila v roku 2010. Pri komparácii Senovej teórie a Dohovoru sú badatel'né jasné prieniky, ktoré je zároveň možné pokladat' za bazálne predpoklady vytvárania rovnakých príležitostí pre osoby so špecifickými potrebami v zmysle antiopresívnej praxe sociálnej práce (Thompson, 2006). Rôznorodost pri aplikácii Senovej teórie do praxe sociálnej práce je spôsobená práve lokálnymi odlišnostami, ktoré v jednotlivých krajinách vychádzajú, o. i., z d’alšej legislatívy, upravujúcej podmienky pre inklúzii osôb so zdravotným postihnutím, odstraňovaním fyzických, štrukturálnych i sociálno-kultúrnych bariér a v presadzovaní myšlienok hodnoty každého člena l’udskej spoločnosti bez výnimky. Súčastou tejto cesty musí byt' aj snaha o vedecké skúmanie problematiky.

Slovensko za ostatné desat́ročia uskutočnilo vel'a aktivít zameraných na naplnenie povinností, ktoré vyplývajú z ratifikácie Dohovoru, no napriek tomu nie je starostlivost' o osoby so špecifickými potrebami 
taká, aby sme mohli byt' s jej úrovňou spokojní. Dosiahnutie takej úrovne starostlivosti o túto sociálnu skupiny predpokladá realizáciu komplexnej a koordinovanej starostlivosti, ktorá je základom pre poskytovanie kvalitnej a efektívnej starostlivosti. Vo vzt́ahu k jedincom so zdravotným postihnutím ide o prepojenie starostlivosti ukotvenej predovšetkým v sociálnom, zdravotníckom a vzdelávacom rezorte. Súčasná prax na Slovensku je koncentrovaná na starostlivost' poskytovanú v rámci jednotlivých sociálnych subsystémov, v dôsledku čoho neprichádza k naplneniu požiadavky holistického prístupu k riešeniu problémov osôb so špecifickými potrebami. Výnimkou je realizácia služby včasnej intervencie, ktorá je od začiatku budovaná na princípoch holistickej a komplexnej starostlivosti o diet́a so špecifickými potrebami a jeho rodinu.

Vychádzajúc z medzinárodných dohovorov, zahraničných príkladov dobrej praxe a tiež z domácich skúseností z oblasti služby včasnej intervencie chceme poukázat́ na prínos sociálneho pracovníka v role prípadového manažéra, ktorý by významnou mierou mohol prispiet́ k realizácii holistického prístupu v starostlivosti o človeka.

\section{Prípadový manažér ako významný subjekt prepojenia systémovej starostlivosti}

Prípadový manažment je postavený na komplexnom posúdení potrieb každého jednotlivca a koordinácii viacerých subjektov v rámci poskytovania sociálnych služieb a sociálnej starostlivosti. Prípadový manažér sa usiluje identifikovat́ potreby klientov k dosiahnutiu maximálne možného stavu fyzického a duševného zdravia jedinca.

Nárast záujmu o prípadový manažment (koncom 20. storočia) posilnilo niekol'ko faktorov, medzi ktoré prioritne patrí skvalitnenie a zefektívnenie služieb sociálnej a zdravotnej starostlivosti a zároveň ich dostupnost' v rámci klientových finančných možností či špecifických potrieb jedinca (Levická, 2020). Viacerí autori zdôrazňujú, že v poskytovaní kvalitnej a efektívnej starostlivosti na komunitnej úrovni je klúučovým nástrojom práve case management, teda prípadový manažment (Powell-Davies, G. et al., 2008; Levická, 2020; Wendt, 2010 a iní). Ako píše Yee (1990, s. 31) prípadový manažment je „proces poskytovania správnej služby pre správneho klienta“. Levická (2020) poukazuje na to, že práve l'udia so zdravotným postihnutím často krát potrebujú pomoc prípadového manažéra. Ross, Curry a Goodwin (2011) zdôrazňujú, že ukotvenie prípadového manažmentu v sociálno-politickom systéme podporujúcom integrovanú a koordinovanú starostlivost' o l’udí so špecifickými potrebami je predpokladom na jeho úspešnú realizáciu.

Stotožňujeme sa s tvrdením Harkey (2017), že prípadový manažment v súčasnosti predstavuje špecifickú medziodborovú prax realizovanú na rozmedzí sociálnej práce a zdravotnej starostlivosti, pričom zastávame názor, že posilnenie postavenia prípadového manažéra v sociálnej práci a v sociálnych službách by mohlo byț jedným z klúčových riešení pri skvalitňovaní starostlivosti o osoby so špecifickými potrebami. Harkey zároveň považuje za hlavný ciel' prípadového manažmentu obhajobu práv klientov s dôrazom na identifikáciu zdrojov k dosiahnutiu optimálneho psychického a fyzického zdravia klienta. V tomto ponímaní zdôrazňuje nezastupitel'né miesto holistického prístupu k človeku. CCMC (2021) považuje prípadový manažment za oblasț špecializovanej praxe v oblasti zdravotníctva a sociálnych služieb. Podl'a Wißmanna (2003, In: Steins, 2012) ciel'om prípadového manažmentu je sprevádzat́ klientov prostredníctvom systému starostlivosti a koordinovat' služby, ktoré sa ich týkajú. Ako píše Levická(2020, s. 89) „súčastou tohto procesu je aj vyhodnotenie možností klienta na získanie najuhodnejších služieb, prípadne hl'adanie zdrojov, ktoré mu môžu pomôct́ získat' potrebné služby. Prípadový manažment je proces smerujúci k sprístupneniu kvalitných a cenovo dostupných služieb“.

NASW (2013) uvádza niekol’ko základných úloh v rámci pracovnej náplne prípadového manažéra, ku ktorým patrí interakcia s klientmi, hodnotenie priorít, silných stránok klienta a výziev, vývoj a implementácia plánu starostlivosti, monitorovanie poskytovania služieb a vyhodnotenie výsledku.

Levická (2020, s. 96) konštatuje, že „prípadový manažér vystupuje ako nestranný, nezainteresovaný poradca, ktorý sa usiluje vybrat' najkvalitnejšie a najefektívnejšie služby a pritom aj služby dostupné klientovým finančným možnostiam“. Prípadový manažér na základe špecifických potrieb klienta v spolupráci so všetkými poskytovatel'mi služieb hl'adá pre klientov vhodných poskytovatel'ov a zdroje v rámci prepojenia zdravotníckych a sociálnych služieb. Dohliada na to, aby poskytovaná starostlivost' bola bezpečná, efektívna, včasná a zameraná na klienta. Súhlasiac s tvrdením viacerých autorov ako napr. Ballew a Mink (1996), Powell a Tahan (2008) konštatujeme, že úlohy a činnosti prípadového manažéra závisia od špecifických potrieb konkrétneho klienta a role, ktorú pri práci s nim zastáva. Môže íst́ o prípadového manažé- 
ra v role advokáta, poradcu či koordinátora. Každá z uvedených rolí má svoje špecifiká. Levická (2020) poukazuje na to, že činnosti prípadového manažéra v role poradcu úzko súvisia s činnost́ami sociálneho pracovníka - poradcu, čo znamená,že v rámci odborných kompetencií by mal prípadový manažér disponovat́ aj poradenskými zručnost́ami a vedomost́ami. Prioritne je dôležité, aby klient porozumel svojmu problému. Zároveň by mal prípadový manažér viest' klienta k zvládaniu svojho problému a k samostatnosti. Súčastou práce je tiež podpora zdrojov klientovej opory. Moxley (2002, In: Roberts, Greene, 2002) poukazuje na to, že v role koordinátora vystupuje prípadový manažér ako organizátor služieb, ktoré klient potrebuje zaistiti pre svoje každodenné fungovanie. Prvý krok začína pri identifikovaní všetkých problémov, čo si vyžaduje spoluprácu s viacerými odborníkmi. K aktivitám prípadového manažéra patrí plánovanie, siet́ovanie služieb a hl'adanie prostriedkov potrebných pre zabezpečenie pomoci klientovi a koordinácia. „Prípadový manažér tak v podstate sprevádza klienta labyrintom služieb, ktoré mu ponúka množstvo poskytovatelov" (Levická, 2020, s. 77). S takmer identickým názorom sa stretneme u autorov Williams a Torrens (1993), ktorí poukazujú na význam prípadového manažmentu pri koordinovaní starostlivosti a pri priamej práci s klientom a jeho rodinou. Z toho vyplýva jedna z hlavných úloh prípadového manažéra, a to prispiet' k nastoleniu nezávislého fungovania klienta. Levická (2020) konštatuje, že prípadový manažér v role advokáta pracuje s klientom, ak niektoré zdroje pomoci sú mu nedostupné alebo ak sú mu odopreté. V rámci tejto role sa prípadový manažér snaží nájst' konsenzus medzi požiadavkami spoločnosti a možnostami klienta. Jeho hlavnou úlohou je priebežne monitorovat' efektivitu balíka služieb starostlivosti, ktoré si s klientom nastavili a spolu za pomoci s inými odborníkmi, vediet' včas vytvorit́ potrebné alternatívy. NASW (2013) tiež poukazuje na to, že prípadoví manažéri musia disponovat́ odbornými vedomostami, znalostami a profesionálnymi zručnostáami z oblasti advokácie, ktorú považuje za klúčovú v rámci systémovej zmeny.

\section{Budovanie integrovanej starostlivosti ako príležitost' pre ukotvenie role prípadového manažéra v slovenskej praxi}

Systém roztrieštenej sociálnej a zdravotnej starostlivosti je na Slovensku v súčasnosti jedným z najzávažnejších problémov a zároveň aj vel'kou výzvou v rámci zefektívnenia a skvalitnenia poskytovaných služieb. Široké spektrum problémov, s ktorými klienti za odborníkmi prichádzajú poukazuje na potrebu multidisciplinárneho prístupu a medzisektorovej spolupráce. K riešeniu situácie by prispelo zavedenie integrovanej starostlivosti, o čom sa v SR diskutuje už viac desat́ročí (Levická, Repková, Cangár a d’alší). Napriek dlhoročnej snahe odborníkov (na Slovensku stále nie sú vytvorené legislatívne ani štrukturálne podmienky, ktoré by podporovali vznik takéhoto typu starostlivosti. Prvý návrh zákona o dlhodobej starostlivosti bol pripravený už v roku 2004. Aktuálne sa pripravuje nový návrh zákona, no reálne riešenie tejto problematiky v praxi nepocitujeme a dodnes neexistuje legislatíva na jej podporu.

Podl'a Kodnera a Spreeuwenberga (2002, In: Repková, 2011) predstavuje integrovaná starostlivost' ucelený súbor metód a modelov vytvárania kooperácie v rámci financovania, administratívneho a organizačného zabezpečenia a poskytovania zdravotných a sociálnych služieb s ciel'om podporit́ kvalitu starostlivosti a kvalitu života prijímatel'ov služieb. Integrovaná starostlivost' je zároveň systémovým riešením s vyššou efektivitou. V súčasnosti je výrazne spájaná s dlhodobou starostlivostóou.

Slovensko malo dlho rozdelenú starostlivostt o človeka medzi viacero rezortov ale už po roku 1990 sa začalo hovorit' o potrebe vytvorenia systémového prepojenia medzi rezortmi MZ SR a MPSVR SR, no k realizácii tejto myšlienky neprišlo. V SR sociálna starostlivost' a zdravotná starostlivost' dodnes predstavujú dva oddelené systémy s minimálnou kooperáciou. Práve nedostatočné prepojenie týchto dvoch oblastí starostlivosti so sebou prináša množstvo problémov v praxi. K najnovším krokom v tejto problematike patrí Programové vyhlásenie vlády Slovenskej republiky na obdobie rokov 2021 - 2024, ktoré vláda SR vydala dňa 28. apríla 2021. Ide o programové vyhlásenie rekonštruovanej vlády po prekonaní vládnej krízy. V tomto vyhlásení vláda SR uvádza, že jednou z jej priorít je práve nevyhnutná reforma dlhodobej starostlivosti. Vláda SR sa zaväzuje pripravit' „novú legislatívu o dlhodobej starostlivosti, ktorá sa zameria na riešenie komplexnej zdravotnej, sociálnej a opatrovatel'skej starostlivosti“(s. 39).

V rámci integrovanej a na človeka orientovanej starostlivosti uvádza WHO niekol’ko základných princípov, ku ktorým patrí aj komplexnost', koordinovanost', holistický prístup, spolupráca a spravodlivost' (Cangár a kol., 2016). Leichsenring a Alazewsky (2004) definujú integrovanú starostlivost' ako koncept poskytovania služieb starostlivosti, v ktorých jednotlivé zložky podpory konajú koordinovane a cielene, 
pričom kladú dôraz na zabezpečovanie nákladovej efektivity, zlepšovanie kvality a zvyšovanie uspokojovania potrieb užívatel'ov a poskytovatel'ov starostlivosti. Integrovaná starostlivost' podl'a Cangára a kol. (2016) predstavuje priestor na zabezpečenie komplexnej, koordinovanej starostlivosti a podpory zdravia jednotlivcov a skupín, ktorí potrebujú podporu presahujúcu jednotlivé rezorty. Práve z toho dôvodu predstavuje jednu z najväčších výziev pre SR. Takto chápaná starostlivost' sa zhoduje aj s poslaním prípadového manažmentu, ktorým je podl'a Neuffera (2007) zabezpečovanie pomoci v prístupe k nevyhnutným službám, ale tiež smerovanie klientov k využívaniu d’alších podporných služieb. Súčastou tohto procesu je aj koordinácia poskytovania jednotlivých služieb.

\section{Diskusia a Záver}

Zahraničné skúsenosti poukazujú na prínos integrovanej starostlivosti pre jedincov so špecifickými potrebami (Leichsenring, Alazewsky 2004; Kodner, 2009; Briggs et al. 2018). Jej prínosom nie je len zvýšenie kvality života jedincov, ktorým je určená, ale potvrdzuje sa aj finančná efektivita starostlivosti zameranej na človeka (Kongstvedt, 1993).

Úspešnost' zavedenia dlhodobej integrovanej starostlivosti je podmienená nielen prijatím vhodnej legislatívy či zabezpečením adekvátneho finančného krytia tejto zmeny. Za bazálny prvok pri budovaní tejto systémovej zmeny pokladáme personálnu podporu. Pri prekonávaní bariér spôsobených dlhoročným sektorovým prístupom k starostlivosti o l’udí so špecifickými potrebami by významnú rolu mohol zohrat' práve sociálny pracovník - prípadový manažér. Toto tvrdenie opierame aj o definíciu prípadového manažmentu CMSA, na ktorú sa odvolávajú Fraser, Perez a Latour (2018), ktorí zdôrazňujú, že prípadový manažment je na spolupráci založený proces, ktorý „zistujuje, plánuje, implementuje, koordinuje, monitoruje a vyhodnocuje možnosti a služby potrebné na uspokojenie zdravotných a sociálnych potrieb jednotlivca prostredníctvom komunikácie a dostupných zdrojov na podporu kvalitného nákladovo efektívneho výsledku“ (In: Levická,2020).

V SR máme skúsenost's fungovaním prípadového manažéra v oblasti starostlivosti o lúudí s psychickými problémami. Nesporným prínosom sociálneho pracovníka, ktorý v systéme zastáva rolu prípadového manažéra je presah jeho práce do iných systémov, zabezpečujúc tak kontakt s prirodzeným prostredím klienta, pomoc pri hl'adaní podporných a terapeutických služieb po ukončení ústavnej liečby, pomoc pri prechode na komunitnú starostlivost' a pod.

Aplikáciou tejto praxe do oblasti starostlivosti o l’udí so špecifickými potrebami je možné očakávat, že prípadový manažér bude klientom nápomocný pri dosahovaní a udržiavaní optimálnej kvality ich života.

Mohlo by sa namietat', že rolu prípadového manažéra nemusí v systéme starostlivosti o osoby so špecifickými potrebami prevziat́ práve sociálny pracovník. Toto tvrdenie je založené na praxi v zahraničí, kde pozíciu prípadového manažéra zastávajú odborníci z rôznych pomáhajúcich profesií, ktorí ale vždy majú absolvované d’alšie vzdelanie zamerané nielen na oblast' prípadového manažmentu, ale aj na oblast' sociálneho systému, aby boli spôsobilí poskytovat' pomoc, podporu a poradenstvo na adekvátnej úrovni. Ďalším argumentom v prospech sociálne práce je priama naviazanost' profesie na obhajobu práv klientov, so špecifickým zameraním na podporu ich nezávislosti a autonómnosti.

\section{Literatura}

Ballew, J. R., Mink, G. (1996). Case Management in Social Work. Springfield, USA : Charles C. Thomas.

Bartlett, M. H., Saunders N. B. (1970). The common base of social work practice. New York : National Association of Social Workers. 224 s. ISBN 0871010542.

Briggs, A. M., Valentijn, P. P., Thiyagarajan, J. A. \& de Caevalho, I. A. (2018). Elements of integrated care approachesforolderpeopleareviewofreviews.BMJOpen,8(4),e021194,doi:10.1136/bmjopen-2017-021194.

Commission for Case Manager Certification (CCMC). (2021). Definition and Philosophy of Case Management. https://ccmcertification.org/about-ccmc/about-case-management/definition-and-philosophy-case-management.

Convention on the Rights of Persons with Disabilities (CRPD). (2006). New York : UN.

Fraser, K., Perez, R., Latour, C. (Eds.) (2018). CMSA`s Integrated Case Management: A Manual for Case Managers by Case Managers. New York: Springer Publishing.

Harkey, J. (2017). Case Management at the Intersection of Social Work and Health Care. Social Work Today, 17(1), s. 20. https://www.socialworktoday.com/archive/011917p20.sh tml. 
Kodner, D. L. (2009) All together now: a conceptual exploration of integrated care. Healthc Q.13 Spec No:6-15. doi: 10.12927/hcq.2009.21091.

Kongstvedt, P. R. (1993). The Managed Health Care Handbook. Maryland : Aspen Publishers, Inc.

Leichsenring, K. \& Alazewsky, A. M. (eds.) (2004). Providing Integrated Health and Social Care for Older Persons. s. 15. European Center Vienna. Ashgate : Wien. ISBN: 0-7546-4196-1.

Levická, J. a kol. (2015). Identita slovenskej sociálnej práce. Trnava : Typi Universitatis Tyrnaviensis. 233 s. ISBN 978-80-8082-872-1.

Levická, J. (2020). Prípadový manažment pre sociálnu prácu. Trnava : UCM v Trnave. 184 s. ISBN 978-80572-0074-1.

Ministerstvo zahraničných vecí Slovenskej republiky (MZV SR). (2010). Zbierka zákonov č. 317/2010. Oznámenie Ministerstva zahraničných vecí Slovenskej republiky. https://www.employment.gov.sk/ files/slovensky/uvod/legislativa/socialna-pomoc-podpora/dohovor-osn-pravach-osob-so-zdravotnym-postihnutim-opcny-protokol-sk-aj.pdf.

Moxley, D. P. (2002). Case Management and Social Rehabilation with SMD Clients. In: Roberts, A. R., Greene, G. J. (2002). Social Workers Desk Reference. Oxford: Oxford University Press.

National Association of Social Workers (NASW). (2013). Social Work Case Management. https://www.socialworkers.org/LinkClick.aspx?fileticket=acrzqmEfhlo\%3D\&portalid=0.

Neuffer, M. (2007). Case Management. Soziale Arbeit mit Einzelnen und Familien. Weinheim/München : Juventa.

Palovičová, Z. (2011). K pojmu sociálneho fungovania. Filozofia, 66(9). http://www.klemens.sav.sk/fiusav/ doc/filozofia/2011/9/833-844.pdf.

Powell, S. K., Tahan, H. A. (2008). CMSA core curriculum for came managent. Phliadelhpia : Lippincott Williams \& Wilkins.

Powell-Davies, G., Williams, A., Larsen, K., Perkins, D., Roland, M., Harris, M. (2008). Coordinating primary health care ananalysis of the out comes of a systematic review. Medical Journal of Australia. 188 (8): 65-68.

Programové vyhlásenie vlády Slovenskej republiky na obdobie rokov 2021 - 2024. (2021). https://www. nrsr.sk/web/Dynamic/DocumentPreview.aspx?DocID=494677.

Rawls, J. (1971). A Theory of Justice. Cambridge, Mass : Harvard University Press.

Rawls, J. (2007). Spravodlivost' ako férovost'. Bratislava: Kalligram. ISBN 8071499110.

Repková, K. (2011). Dlhodobá starostlivost' v kontexte integrovanej sociálnej práce. Bratislava : IVPR. 257 s. ISBN 978-80-7138-132-7.

Ross, S., Curry, N., Goodwin, N. (2011). Casemanagment. What it is and how it can best be implemented. London : The Kings Fund.

https://www.kingsfund.org.uk/sites/default/files/CaseManagement-paper-The-Kings-Fund-Paper-November-2011_0.pdf.

Sen, A. (2010). The Idea of Justice. London: Penguin Books. 476 s. ISBN 978-01410-3785-1.

Steins, G. (2012). Psychologie und Case Management in der Sozialen Arbeit. Langerich : Pabst Science Publishers.

Thompson, N. (2006). Anti-discriminatory Practice. Basingstoke : Palgrave Macmillan. 208 s. ISBN 0333803132.

Wendt, W. R. (2010). Case-Management im Sozial- und Gesundheitswesen. Eine Einführung (5. Aufl.). Freiburg im Breisgau: Lambertus-Verlag.

Williams, S. J., Torrens, P. R. (1993). Intorduction to health services. New York : Delmar.

Yee, B. W. K. (1990). Variations in Aging: Minorities. Galveston : University of Texas Medical Branch.

Tento príspevok je podporený projektom „Pracovné metódy a postupy sociálnych pracouníkov v zariadeniach pre seniorov“s číslom FPPV-08-2021. 


\section{Informácie o autoroch}

\section{prof. PhDr. Mgr. Jana Levická, PhD.}

V súčasnosti pôsobí ako vysokoškolská profesorka na Katedre sociálnych služieb a poradenstva FSV UCM vTrnave (SR). Vo vedeckej a pedagogickej oblasti sa zameriava predovšetkým na teóriu a metódy sociálnej práce, dějiny sociálnej práce, sociálnu ochranu a metodológiu. Dlhodobo spolupracuje s Inštitútom sociálnej práce FF UHK v Hradci Králové (ČR). Je členkou viacerých vedeckých a odborových rád doma i v zahraničí.

E-mail: jana.levicka@ucm.sk

\section{Mgr. Michaela Vaceková}

Pôsobí ako interná doktorandka na Katedre sociálnych služieb a poradenstva FSV UCM v Trnave (SR) v študijnom odbore sociálna práca. Oblast́ami jej akademického záujmu sú predovšetkým sociálna práca v sociálnych službách, metódy sociálnej práce, činnosti a úlohy sociálnych pracovníkov vykonávané v praxi sociálnej práce.

E-mail: vacekova1@ucm.sk

\section{Mgr. Emma Valigurská}

Pôsobí ako interná doktorandka na Katedre sociálnych služieb a poradenstva FSV UCM v Trnave (SR) v študijnom odbore sociálna práca. Oblastáami jej akademického záujmu sú predovšetkým sociálna práca v sociálnych službách, vybrané aspekty sociálnej práce a úlohy sociálnych pracovníkovv Ozbrojených silách SR. E-mail: valigurska1@ucm.sk 